\title{
A STUDY OF EXPOSURE TO ENVIRONMENTAL TEMPERATURES IN A POPULATION SAMPLE USING THE TEMPERATURE SAMI
}

\author{
R. T. CORKHILL AND W. W. HOLLAND \\ Department of Clinical Epidemiology and Social Medicine, St. Thomas's Hospital Medical School, London, S.E.1. \\ R. H. FOX AND M. S. R. MEE \\ National Institute for Medical Research (Hampstead Laboratories), Holly Hill, London, N.W.3.
}

Associations have been found between respiratory mortality and low temperature accompanied by high levels of humidity (Boyd, 1960) and between admission to hospital for acute respiratory disease and low temperature (Holland, Spicer, and Wilson, 1961; Holland and Spicer, 1966). These associations were most marked among those aged 45 or more years. In recent years there has been increasing concern about the problem of accidental hypothermia, particularly among the elderly (British Medical Association, 1964; Royal College of Physicians of London, 1966). It has been suggested that many old people may be living in inadequately heated accommodation or may fail to make full use of the heating facilities available (Lancet, 1970; Eddy, Payne, Salvosa, and Wheeler, 1970). An association between low mouth temperatures in old people and low temperatures in their living accommodation has also been demonstrated (Report by the Hypothermia Sub-committee of the Welfare Group of the Society of Medical Officers of Health, 1968; Eddy et al., 1970; Williams, 1968), although the significance of such an association needs to be treated with great caution (Fox et al., 1971).

Until recently, the measurement of an individual's exposure to environmental temperature has depended on spot readings taken by an observer visiting the accommodation or by placing instruments to record the temperatures in a number of rooms with subsequent assumptions about the amount of time likely to have been spent in the different locations. However, the development of the temperature SAMI (Socially Acceptable Monitoring Instrument) (Baker, Humphrey, and Wolff, 1967; Humphrey and Wolff, 1968) has made it possible to monitor the temperature of the environment close to an individual throughout the day and night, wherever he or she happens to be.

The present study reports the results of the first field trial in January 1968 of the production model of the temperature SAMI. In addition to testing the new equipment, the aim was to identify any variations in exposure to environmental temperatures which might exist between individuals of different age, sex, and social class, with different housing or working conditions or using different forms of heating. An attempt was also made to identify any difference in exposure to environmental temperature between those with chronic respiratory symptoms and those without such symptoms.

Study SAmple

\section{METHOD}

The study was carried out on a subsample of individuals aged 35 to 74 years, who were involved in an earlier survey on cardiorespiratory symptoms undertaken in North Lambeth (Holland, 1967). The subjects fell into one of two groups: 'normal' individuals without any positive evidence of chronic respiratory disease, and individuals who had reported chronic respiratory symptoms. The latter group was subdivided into those with persistent cough and phlegm and chest illness. Ten individuals were included in each disease group, five in each group being aged 65 years and over. 'Normal' individuals were sampled according to a balanced sex, age, and social class design having four 10-year age groups and three social class groups (I + II, III, and IV $+V$ ). Five individuals were included in each cell. The total sample, therefore, consisted of No 140 individuals. The details of the sampling scheme are shown in Table I.

\section{Monitoring SCHEdUle}

The personal environmental temperature of each individual was measured on two consecutive days and nights. Recorders were changed night and morning to give separate estimates for the day and 
TABLE I

SAMPLE DESIGN

(a) NORMAL INDIVIDUALS

\begin{tabular}{|c|c|c|c|c|c|c|c|c|c|}
\hline \multirow[b]{3}{*}{ Social Class } & \multicolumn{9}{|c|}{ Age (yr) } \\
\hline & \multicolumn{4}{|c|}{ Male } & \multicolumn{5}{|c|}{ Female } \\
\hline & $35-$ & $45-$ & 55 & $65+$ & $35-$ & $45-$ & 55 & $65+$ & Total \\
\hline $\begin{array}{l}I+I I \\
\text { III }+ \text { IV }\end{array}$ & $\begin{array}{l}5 \\
5 \\
5\end{array}$ & $\begin{array}{l}5 \\
5 \\
5\end{array}$ & $\begin{array}{l}5 \\
5 \\
5\end{array}$ & $\begin{array}{l}5 \\
5 \\
5\end{array}$ & $\begin{array}{l}5 \\
5 \\
5\end{array}$ & $\begin{array}{l}5 \\
5 \\
5\end{array}$ & $\begin{array}{l}5 \\
5 \\
5\end{array}$ & $\begin{array}{l}5 \\
5 \\
5\end{array}$ & $\begin{array}{l}40 \\
40 \\
40\end{array}$ \\
\hline Total & 15 & 15 & 15 & 15 & 15 & 15 & 15 & 15 & 120 \\
\hline
\end{tabular}

(b) INDIVIDUALS REPORTING CHRONIC RESPIRATORY SYMPTOMS

\begin{tabular}{l|c|c|c|c}
\hline Symptoms & \multicolumn{2}{|c|}{ Age (yr) } \\
\hline Persistent cough and phlegm & $<65$ & $65+$ & Total \\
\hline Persistent cough and phlegm + chest illness & 5 & 5 & 10 \\
\hline Total & 5 & 5 & 10 \\
\hline
\end{tabular}

night temperatures. Night was defined as the period the subject spent in bed when the instrument was placed on a chair or table at the bedside. Day was defined as the period from rising to going to bed. During the daytime, the temperature probe was attached to the external surface of the outer layer of clothing in the upper lateral chest region.
SAMI Measurement TeChNiques

A total of 24 temperature SAMIs was employed. The SAMI Equipment (manufactured by the T.E.M. Group, Gatwick Road, Crawley, Sussex) is illustrated in Figure 1. The small size and weight of the instrument is achieved by using a sensitive and reversible electrochemical integrator $(E$ cell) as the data store. After use the stored charge is measured and the $\mathrm{E}$ cell is reset by a replay machine. The SAMIs were adjusted to integrate deviations of the personal environment temperature from $25^{\circ} \mathrm{C}$ downwards with a sensitivity of $0 \cdot 15 \mu \mathrm{A} /{ }^{\circ} \mathrm{C}$. Linearity was satisfactory from $25^{\circ} \mathrm{C}$ to $15^{\circ} \mathrm{C}$, but recordings below $15^{\circ} \mathrm{C}$ had to be adjusted for non-linearity using a calibration curve. Each instrument was checked before and after use on each individual and any faults were noted.

A total of $150 \mathrm{E}$ cell recorders was used. During the survey, 21 were found to have developed faults and all data from these recorders have been excluded from the analysis. Recorders were rejected on the basis of two tests, each repeated twice: (1) if they had gained 10 or more counts after complete discharge 24 hours earlier; (2) following complete discharge, recorders were charged at $1.94 \mu \mathrm{A}$ for one hour and then measured on the playback machine to see whether they gave the required count of 155 . Recorders giving counts outside the limits 152 to 
158 on the first occasion and 147 to 163 on the other were rejected. In vitro tests on the SAMIs and recorders at $12^{\circ} \mathrm{C}$ and $21^{\circ} \mathrm{C}$ gave the required accuracy of $\pm 0.23^{\circ} \mathrm{C}$ for the temperature measurements. To fix the thermometer probe to the clothing, the thermistor was mounted on the outer surface of a plastic cup which was attached to the clothing by a ring of double-sided sticky tape. This proved very satisfactory; it adhered well and yet could be removed with ease and replaced on almost all types of clothing.

The equipment in kit form was taken to the subjects by home visitors. This contained the SAMI, four recorders in envelopes upon which the subjects wrote the date and time they were used, the thermistor probe, sticky rings, and an instruction sheet. The home visitor explained the use of the instrument on the initial visit and ensured that the instructions had been followed when collecting it $\mathbf{4 8}$ hours later. The visitor also obtained information on heating, housing, and working conditions. This included the number of persons occupying the household, the nature of employment, the total number of hours spent outdoors during the measurement period, and the type of living room and bedroom heating used.

The Meteorological Office supplied hourly values for the dry-bulb temperature at Kew Observatory, from which the mean day and night temperatures were calculated and are illustrated in Figure 2.

\section{RESULTS}

Of the 140 subjects included in the original design, 24 subjects proved unwilling to participate and all results for a further four subjects (i.e., 16 measurements) had to be excluded. For the remaining 112 subjects, 108 of the 448 measurements possible were

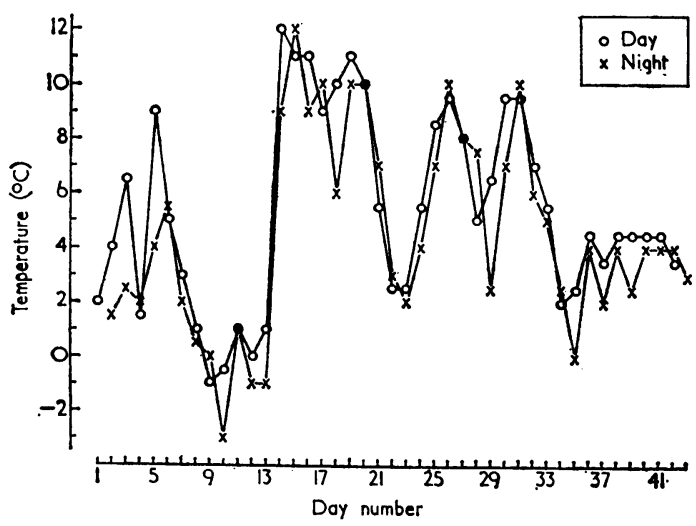

FIG. 2.-Average day and night air temperatures $\left({ }^{\circ} \mathrm{C}\right)$ at $\mathrm{Kew}$ Observatory for the survey period 1 January to 12 February, 1968.
TABLE II

NUMBERS AND CAUSES OF FAILED MEASUREMENTS

\begin{tabular}{l|c}
\hline \multicolumn{1}{c|}{ Cause of Failure } & $\begin{array}{c}\text { No. of } \\
\text { Missing Values }\end{array}$ \\
\hline SAMI instrument failure & 12 \\
Faulty recorder & 36 \\
Subject failed to use equipment correctly & 21 \\
Instrument used for less than five hours & 52 \\
Miscellaneous & 3 \\
\hline Total & 124 \\
\hline
\end{tabular}

not obtained. The reasons for missing values are set out in Table II.

The largest single cause for loss of data was the failure to complete a measurement on one or other of the days. This was because the home visitors found it difficult to arrange their visits so that a complete 48-hour period of recording was obtained. Hence either the first or second day recording often had to be curtailed. Table III shows the numbers of individuals with successful measurements for each period.

TABLE III

NUMBERS OF INDIYIDUALS WITH SUCCESSFUL MEASUREMENTS FOR EACH PERIOD

\begin{tabular}{|c|c|c|}
\hline Period of Measurement & $\begin{array}{c}\text { No. of Subjects } \\
\text { with } \\
\text { Complete Data }\end{array}$ & $\begin{array}{l}\% \text { of Original } \\
\text { Sample }\end{array}$ \\
\hline $\begin{array}{l}\text { Night } 1 \\
\text { Night } 2 \\
\text { Day } 1 \\
\text { Day } 2\end{array}$ & $\begin{array}{r}94 \\
102 \\
57 \\
87\end{array}$ & $\begin{array}{l}67 \cdot 1 \\
72 \cdot 9 \\
40 \cdot 7 \\
62 \cdot 1\end{array}$ \\
\hline $\begin{array}{l}\text { Nights } 1 \text { and } 2 \\
\text { Days } 1 \text { and } 2\end{array}$ & $\begin{array}{l}87 \\
46\end{array}$ & $\begin{array}{l}62 \cdot 1 \\
32 \cdot 9\end{array}$ \\
\hline $\begin{array}{l}\text { Total period (days } 1 \text { and } 2 \\
\text { and nights } 1 \text { and } 2 \text { ) }\end{array}$ & 35 & 25.0 \\
\hline
\end{tabular}

The mean day and night personal environment temperatures by sex are shown in Table IV. No consistent pattern of differences between males and

TABle IV

MEAN PERSONAL ENVIRONMENT TEMPERATURES FOR EACH PERIOD ACCORDING TO SEX

\begin{tabular}{l|l|c|c}
\hline Sex & $\begin{array}{c}\text { Period of } \\
\text { Measurement }\end{array}$ & $\begin{array}{c}\text { Mean Temp. } \\
\left({ }^{\circ} \mathrm{C}\right)\end{array}$ & $\begin{array}{c}\text { No. of Individuals } \\
\text { Successfully Measured }\end{array}$ \\
\cline { 2 - 3 } Male & $\begin{array}{c}\text { Day 1 } \\
\text { Day 2 }\end{array}$ & $\begin{array}{c}20 \cdot 73 \\
19 \cdot 43\end{array}$ & 23 \\
& Night 1 & $12 \cdot 15$ & \\
Night 2 & 11.95 & 45 \\
\hline \multirow{3}{*}{ Female } & Day 1 & $22 \cdot 48$ & 23 \\
& Day 2 & $21 \cdot 18$ & 25 \\
& Night 1 & $11 \cdot 77$ & 42 \\
\hline
\end{tabular}


TABLE $V$

MEAN PERSONAL ENVIRONMENT TEMPERATURE FOR EACH PERIOD ACCORDING TO AGE

\begin{tabular}{|c|c|c|c|}
\hline $\begin{array}{l}\text { Age } \\
\text { (yr) }\end{array}$ & $\begin{array}{l}\text { Period of } \\
\text { Measurement }\end{array}$ & $\begin{array}{c}\text { Mean Temp. } \\
\left({ }^{\circ} \mathbf{C}\right)\end{array}$ & $\begin{array}{l}\text { No. of Individuals } \\
\text { Successfuly Measured }\end{array}$ \\
\hline$<45$ & $\begin{array}{l}\text { Day } 1 \\
\text { Day } 2 \\
\text { Night } 1 \\
\text { Night } 2\end{array}$ & $\begin{array}{l}20.95 \\
19.20 \\
11.67 \\
11.91\end{array}$ & $\begin{array}{r}6 \\
16\end{array}$ \\
\hline $45-54$ & $\begin{array}{l}\text { Day } 1 \\
\text { Day } 2 \\
\text { Night } 1 \\
\text { Night } 2\end{array}$ & $\begin{array}{l}20.86 \\
19.93 \\
12.68 \\
12.80\end{array}$ & $\begin{array}{r}9 \\
26\end{array}$ \\
\hline $55-64$ & $\begin{array}{l}\text { Day } 1 \\
\text { Day } 2 \\
\text { Night } 1 \\
\text { Night } 2\end{array}$ & $\begin{array}{l}21.48 \\
18.86 \\
10.92 \\
10.92\end{array}$ & $\begin{array}{l}11 \\
17\end{array}$ \\
\hline $65+$ & $\begin{array}{l}\text { Day } 1 \\
\text { Day } 2 \\
\text { Night } 1 \\
\text { Night } 2\end{array}$ & $\begin{array}{l}22 \cdot 20 \\
21 \cdot 59 \\
12 \cdot 11 \\
12 \cdot 81\end{array}$ & $\begin{array}{l}20 \\
28\end{array}$ \\
\hline
\end{tabular}

females was found, although females tended to have slightly higher personal environment temperatures than males during the day. For both sexes, mean temperatures during the day were considerably higher than at night and the mean temperature on the first day tended to be higher than on the second.

Mean temperatures according to age are shown in Table V. In general, the day temperatures recorded for the younger age groups tended to be lower than those recorded for older individuals.

Very little difference was found between the mean personal environment temperatures of individuals from different social class groups, though those in social classes IV and V appeared to have a slightly higher level of temperature at night than those in social classes I, II, and III (Table VI). No consistent differences were found between the temperatures of individuals with or without respiratory symptoms (Table VII) and no relationship was found between day or night personal environment temperatures

TABLE VI

MEAN PERSONAL ENVIRONMENT TEMPERATURE FOR EACH PERIOD ACCORDING TO SOCIAL CLASS

\begin{tabular}{|c|c|c|c|}
\hline $\begin{array}{l}\text { Social } \\
\text { Class }\end{array}$ & $\begin{array}{c}\text { Period of } \\
\text { Measurement }\end{array}$ & $\begin{array}{c}\text { Mean Temp. } \\
\left({ }^{\circ} \mathbf{C}\right)\end{array}$ & $\begin{array}{l}\text { No. of Individuals } \\
\text { Successfully Measured }\end{array}$ \\
\hline $\mathbf{I}+\mathbf{I I}$ & $\begin{array}{l}\text { Day 1 } \\
\text { Day 2 } \\
\text { Night } 1 \\
\text { Night } 2\end{array}$ & $\begin{array}{l}21 \cdot 46 \\
20 \cdot 28 \\
11 \cdot 72 \\
12 \cdot 38\end{array}$ & $\begin{array}{l}17 \\
23\end{array}$ \\
\hline III & $\begin{array}{l}\text { Day } 1 \\
\text { Day } 2 \\
\text { Night } 1 \\
\text { Night } 2\end{array}$ & $\begin{array}{l}21 \cdot 45 \\
19.67 \\
11.67 \\
11.76\end{array}$ & $\begin{array}{l}15 \\
32\end{array}$ \\
\hline $\mathbf{I V}+\mathbf{V}$ & $\begin{array}{l}\text { Day } 1 \\
\text { Day } 2 \\
\text { Night } 1 \\
\text { Night } 2\end{array}$ & $\begin{array}{l}21.93 \\
21.01 \\
12.43 \\
12.71\end{array}$ & $\begin{array}{l}14 \\
32\end{array}$ \\
\hline
\end{tabular}

TABLE VII

MEAN PERSONAL ENVIRONMENT TEMPERATURE FOR EACH PERIOD ACCORDING TO PRESENCE, ABSENCE, AND SEVERITY OF RESPIRATORY SYMPTOMS

\begin{tabular}{|c|c|c|c|}
\hline Illness & $\begin{array}{l}\text { Period of } \\
\text { Measurement }\end{array}$ & $\underset{\left({ }^{\circ} \mathbf{C}\right)}{\text { Mean Temp. }}$ & $\begin{array}{c}\text { No. of Individuals } \\
\text { Successfully Measured }\end{array}$ \\
\hline $\begin{array}{l}\text { No } \\
\text { symptoms }\end{array}$ & $\begin{array}{l}\text { Day } 1 \\
\text { Day } 2 \\
\text { Night } 1 \\
\text { Night } 2\end{array}$ & $\begin{array}{l}21 \cdot 60 \\
20 \cdot 12 \\
12 \cdot 04 \\
12 \cdot 19\end{array}$ & $\begin{array}{l}36 \\
76\end{array}$ \\
\hline $\begin{array}{l}\text { Cough } \\
\text { and } \\
\text { phlegm }\end{array}$ & $\begin{array}{l}\text { Day } 1 \\
\text { Day } 2 \\
\text { Night } 1 \\
\text { Night } 2\end{array}$ & $\begin{array}{l}21.92 \\
21.95 \\
12.74 \\
11.31\end{array}$ & $\begin{array}{l}4 \\
5\end{array}$ \\
\hline $\begin{array}{l}\text { Cough, } \\
\text { phlegm } \\
\text { and chest } \\
\text { illness }\end{array}$ & $\begin{array}{l}\text { Day } 1 \\
\text { Day } 2 \\
\text { Night } 1 \\
\text { Night } 2\end{array}$ & $\begin{array}{l}21 \cdot 39 \\
20 \cdot 31 \\
10 \cdot 40 \\
14 \cdot 68\end{array}$ & $\begin{array}{l}6 \\
6\end{array}$ \\
\hline
\end{tabular}

and the number of individuals occupying the household (Table VIII).

There was found to be no relationship between the personal environment temperatures and the corresponding external air temperature during the day, except when the external temperature was less than $0.0^{\circ} \mathrm{C}$, although this occurred on only five occasions. By contrast, there appears to be a direct relationship between the personal environment temperature and external air temperature at night (Table IX). The analysis of mean personal environment temperatures in relation to the type of heating used demonstrated that, during the day, individuals using coal heating tended to be exposed to lower temperatures than those using gas, electricity or paraffin, while at night individuals with central

\section{TABLE VIII}

MEAN PERSONAL ENVIRONMENT TEMPERATURE FOR EACH PERIOD ACCORDING TO NUMBER OF PERSONS OCCUPYNG HOUSEHOLD

\begin{tabular}{|c|c|c|c|}
\hline $\begin{array}{l}\text { Persons per } \\
\text { Household }\end{array}$ & $\begin{array}{l}\text { Period of } \\
\text { Measurement }\end{array}$ & $\underset{\left({ }^{\circ} \mathrm{C}\right)}{\operatorname{Mean}}$ & $\begin{array}{l}\text { No. of Individuals } \\
\text { Successfully Measured }\end{array}$ \\
\hline 1 & $\begin{array}{l}\text { Day } 1 \\
\text { Day } 2 \\
\text { Night } 1 \\
\text { Night } 2\end{array}$ & $\begin{array}{l}21 \cdot 20 \\
21 \cdot 20 \\
11.08 \\
12.65\end{array}$ & $\begin{array}{r}7 \\
13\end{array}$ \\
\hline 2 & $\begin{array}{l}\text { Day } 1 \\
\text { Day } 2 \\
\text { Night } 1 \\
\text { Night } 2\end{array}$ & $\begin{array}{l}22 \cdot 25 \\
20 \cdot 57 \\
11 \cdot 14 \\
11 \cdot 25\end{array}$ & $\begin{array}{l}22 \\
30\end{array}$ \\
\hline 3 & $\begin{array}{l}\text { Day 1 } \\
\text { Day } 2 \\
\text { Night } 1 \\
\text { Night } 2\end{array}$ & $\begin{array}{l}21 \cdot 13 \\
20 \cdot 17 \\
12 \cdot 10 \\
11 \cdot 62\end{array}$ & $\begin{array}{r}8 \\
18\end{array}$ \\
\hline 4 & $\begin{array}{l}\text { Day } 1 \\
\text { Day } 2 \\
\text { Night } 1 \\
\text { Night } 2\end{array}$ & $\begin{array}{l}18 \cdot 19 \\
18 \cdot 41 \\
12 \cdot 89 \\
14 \cdot 62\end{array}$ & $\begin{array}{r}3 \\
13\end{array}$ \\
\hline$>4$ & $\begin{array}{l}\text { Day } 1 \\
\text { Day } 2 \\
\text { Night } 1 \\
\text { Night } 2\end{array}$ & $\begin{array}{l}22 \cdot 13 \\
19 \cdot 40 \\
13 \cdot 66 \\
12 \cdot 81\end{array}$ & $\begin{array}{r}6 \\
13\end{array}$ \\
\hline
\end{tabular}


TABLE IX

MEAN ENVIRONMENTAL TEMPERATURE FOR EACH PERIOD ACCORDING TO RECORDED METEOROLOGICAL TEMPERATURE

\begin{tabular}{|c|c|c|c|}
\hline $\begin{array}{l}\text { Met. Temp. } \\
\quad\left({ }^{\circ} \mathrm{C}\right)\end{array}$ & $\begin{array}{c}\text { Period of } \\
\text { Measurement }\end{array}$ & $\begin{array}{c}\text { Mean Temp. } \\
\left({ }^{\circ} \mathbf{C}\right)\end{array}$ & $\begin{array}{l}\text { No. of Individuals } \\
\text { Successfully Measured }\end{array}$ \\
\hline$<0$ & $\begin{array}{l}\text { Day } 1 \\
\text { Day } 2\end{array}$ & $\begin{array}{ll}14 \cdot 84 \\
17 \cdot 13\end{array}$ & $\begin{array}{l}1 \\
4\end{array}$ \\
\hline 0 & $\begin{array}{l}\text { Day } 1 \\
\text { Day } 2\end{array}$ & $\begin{array}{l}21 \cdot 67 \\
19 \cdot 82\end{array}$ & $\begin{array}{r}14 \\
7\end{array}$ \\
\hline $3-$ & $\begin{array}{l}\text { Day } 1 \\
\text { Day } 2\end{array}$ & $\begin{array}{l}21.92 \\
21.01\end{array}$ & $\begin{array}{r}11 \\
7\end{array}$ \\
\hline $6-$ & $\begin{array}{l}\text { Day } 1 \\
\text { Day } 2\end{array}$ & $\begin{array}{l}21.96 \\
19 \cdot 61\end{array}$ & $\begin{array}{r}4 \\
13\end{array}$ \\
\hline 9- & $\begin{array}{l}\text { Day } 1 \\
\text { Day } 2\end{array}$ & $\begin{array}{l}21 \cdot 66 \\
21.92\end{array}$ & $\begin{array}{l}16 \\
13\end{array}$ \\
\hline $11+$ & $\begin{array}{l}\text { Day } 1 \\
\text { Day } 2\end{array}$ & $\overline{19.87}$ & $\overline{2}$ \\
\hline$<-2$ & $\begin{array}{l}\text { Night } 1 \\
\text { Night } 2\end{array}$ & $\begin{array}{l}7 \cdot 14 \\
7 \cdot 14\end{array}$ & $\begin{array}{l}4 \\
4\end{array}$ \\
\hline$-2-$ & $\begin{array}{l}\text { Night } 1 \\
\text { Night } 2\end{array}$ & $\begin{array}{r}9 \cdot 46 \\
10 \cdot 14\end{array}$ & $\begin{array}{l}14 \\
10\end{array}$ \\
\hline$-1-$ & $\begin{array}{l}\text { Night } 1 \\
\text { Night } 2\end{array}$ & $\begin{array}{l}12 \cdot 55 \\
11 \cdot 32\end{array}$ & $\begin{array}{l}15 \\
23\end{array}$ \\
\hline 4 & $\begin{array}{l}\text { Night } 1 \\
\text { Night } 2\end{array}$ & $\begin{array}{l}11.91 \\
13 \cdot 27\end{array}$ & $\begin{array}{l}23 \\
26\end{array}$ \\
\hline $7-$ & $\begin{array}{l}\text { Night } 1 \\
\text { Night } 2\end{array}$ & $\begin{array}{l}13.48 \\
12.81\end{array}$ & $\begin{array}{l}17 \\
14\end{array}$ \\
\hline $10+$ & $\begin{array}{l}\text { Night } 1 \\
\text { Night } 2\end{array}$ & $\begin{array}{l}13 \cdot 34 \\
15 \cdot 30\end{array}$ & $\begin{array}{l}14 \\
10\end{array}$ \\
\hline
\end{tabular}

heating appeared to be exposed to considerably higher temperatures than those using other forms of heating (Table X).

In view of the many different variables examined, it was necessary to apply a multivariate technique in order to determine their relative importance and their separate effects in the presence of the other variables acting concurrently on the personal environment temperature. This was done using the general linear hypothesis.

The adoption of a single regression model for day and night measurements would not, however, have been satisfactory as day and night temperatures are not strictly comparable. In addition, such an analysis would have had to be restricted to those subjects with four successful measurements (35 individuals). It was, therefore, decided to analyse day and night measurements separately and to include as independent variables in the two models only those variables which could reasonably be expected to explain variation in day and night personal environment temperatures.

The only variable that appeared to have any influence on the mean day temperature was the type of heating used: individuals using coal heating tended to have lower standardized personal en-
TABLE X

MEAN PERSONAL ENVIRONMENT TEMPERATURE IN LIVING ROOM AND BEDROOM FOR DAY AND NIGHT RESPECTIVELY ACCORDING TO TYPE OF HEATING USED

\begin{tabular}{|c|c|c|c|}
\hline $\begin{array}{l}\text { Type of } \\
\text { Heating }\end{array}$ & $\begin{array}{c}\text { Period of } \\
\text { Measurement }\end{array}$ & $\underset{\left({ }^{\circ} \mathrm{C}\right)}{\operatorname{Mean}}$ & $\begin{array}{l}\text { No. of Individuals } \\
\text { Successfully Measured }\end{array}$ \\
\hline None & $\begin{array}{l}\text { Day } 1 \mathrm{~L} \\
\text { Day } 2 \\
\text { Night } 1 \mathrm{~B} \\
\text { Night } 2\end{array}$ & $\begin{array}{l}\overline{ } \\
11 \cdot 53 \\
11 \cdot 31\end{array}$ & - \\
\hline Coal & $\begin{array}{l}\text { Day 1L } \\
\text { Day } 2 \\
\text { Night 1B } \\
\text { Night } 2\end{array}$ & $\begin{array}{l}19 \cdot 89 \\
19 \cdot 70 \\
11 \cdot 45 \\
16 \cdot 31\end{array}$ & $\begin{array}{r}13 \\
2\end{array}$ \\
\hline Gas & $\begin{array}{l}\text { Day 1L } \\
\text { Day } 2 \\
\text { Night } 1 B \\
\text { Night } 2\end{array}$ & $\begin{array}{r}22 \cdot 45 \\
20 \cdot 35 \\
9 \cdot 66 \\
10 \cdot 26\end{array}$ & $\begin{array}{r}11 \\
6\end{array}$ \\
\hline Electricity & $\begin{array}{l}\text { Day 1L } \\
\text { Day } 2 \\
\text { Night 1B } \\
\text { Night } 2\end{array}$ & $\begin{array}{l}21.69 \\
19.94 \\
13.19 \\
13.75\end{array}$ & $\begin{array}{l}18 \\
18\end{array}$ \\
\hline Paraffin & $\begin{array}{l}\text { Day 1L } \\
\text { Day } 2 \\
\text { Night 1B } \\
\text { Night } 2\end{array}$ & $\begin{array}{l}24.47 \\
23.77 \\
11.92 \\
13.41\end{array}$ & $\begin{array}{l}4 \\
7\end{array}$ \\
\hline $\begin{array}{l}\text { Central } \\
\text { heating }\end{array}$ & $\begin{array}{l}\text { Day 1L } \\
\text { Day } 2 \\
\text { Night 1B } \\
\text { Night } 2\end{array}$ & $\begin{array}{l}\overline{-} \\
17 \cdot 11 \\
18 \cdot 41\end{array}$ & - \\
\hline
\end{tabular}

$\mathbf{L}=$ living room heating

$\mathrm{B}=$ bedroom heating

vironment temperatures than those using othe forms of heating. However, this difference was only significant on the first day. In the analysis of night temperature, significant differences were found for the level of external temperature and type of heating used. Individuals tended to have lower personal environment temperatures on night 1 when the external temperature was low, individuals with central heating being exposed to higher standardized temperatures than those having other forms of bedroom heating. The latter difference was highly significant on both nights. Individuals with respiratory symptoms also tended to be exposed to significantly higher standardized night temperature on night 2 than 'normal' individuals.

\section{Discussion}

The pilot study of the temperature SAMI (Humphrey and Wolff, 1968) has demonstrated that the instrument can be successfully used to investigate the environmental thermal exposure of individuals in the general population for continuous periods of up to $\mathbf{4 8}$ hours. The equipment itself performed well and relatively few measurements were lost through SAMI instrument failures. The recorders proved less reliable and the authors would strongly recommend other potential users to apply stringent tests similar to those described here. Human errors by 
both observers and subjects accounted for the majority of the missing values. There were relatively few complaints of difficulty or serious inconvenience from the subjects, but this is undoubtedly a tribute to the very high quality of the home visitors who worked in the study.

The analysis of the data obtained on the 112 subjects does not reveal many significant relationships between the personal environment temperatures of the individuals and the possible modifying factors considered. In view of the relatively small sample studied and the great complexity of the variables involved, this is perhaps not surprising. The results show significant effects from the type of heating used both during the day and at night. Individuals occupying houses heated by coal fires as opposed to other forms of heating were exposed to lower temperatures during the day, and the presence of central heating was associated with higher bedroom temperatures at night.

The absence of any differences between the social classes is interesting but must be considered with respect to the smallness of the sample size.

The results emphasise the remarkably low bedroom temperatures in which people choose to sleep and a failure to follow the BMA recommendation (British Medical Association, 1964) that elderly people should sleep in a warm bedroom. Since the association between the development of hypothermia of the elderly and low environmental temperature is firmly established (British Medical Association, 1964; Royal College of Physicians of London, 1966) this is disturbing and indicates the desirability of further studies on larger samples.

The results do not suggest that individuals with established respiratory disease choose to live in warmer conditions than those without respiratory symptoms.

Finally, although this survey was conducted at the coldest period of the year, the day-time personal thermal environments are surprisingly low and $14 \%$ of all readings were below the level of $18 \cdot 3^{\circ} \mathrm{C}$, recommended by the Parker-Morris Committee as the minimum temperature able to be maintained in living rooms in cold weather (Ministry of Housing and Local Government, 1961).

\section{Summary}

The results are given of a pilot study using the temperature SAMI to investigate the thermal exposure of 112 individuals for continuous periods of up to 48 hours while following their normal occupations. In general, the instrument performed well but the associated data recorders proved less reliable. Attempts to determine whether individual differences in thermal exposure may be predicted by difference in sex, age, social class, and the number of persons living in the accommodation produced negative results. Thermal exposure was significantly influenced by the type of heating used in the accommodation. The thermal exposure of a group of subjects with respiratory symptoms did not consistently differ from those without symptoms.

These findings underline the low temperatures in living accommodation, especially bedrooms, accepted by the general population during cold weather in this country.

This work was supported in part by a grant from the Department of Health and Social Security. The authors would like to thank Dr. I. Z. Roth for suggesting the methods of analysis used and the four fieldworkers, Mrs Corinne Moore, Miss Jennifer Saville-Sneath, Miss Jennifer Dale, and Mrs Helen Kaplan, for their help in collecting the data.

\section{REFERENCES}

Baker, J. A., Humphrey, S. J. E., and WolfF, H. S. (1967). Socially acceptable monitoring instruments (SAMI). J. Physiol. (Lond.), 188, 4P.

BOYD, J. T. (1960). Climate, air pollution, and mortality. Brit. J. prev. soc. Med., 14, 123.

British Medical Association (1964). Accidental hypothermia in the elderly. Brit. med.J., 2, 1255.

Eddy, T. P., Payne, P. R., Salvosa, C., and Wheeler, E. F. (1970). Body temperatures in the elderly. Lancet, 2, 1088.

Fox, R. H., Woodward, P. M., Fry, A. J., Collins, J. C., and MacDonald, I. C. (1971). Diagnosis of accidental hypothermia of the elderly. Lancet, 1, 424.

Holland, W. W. (1967). St. Thomas's Health Survey in Lambeth, Report III.

- and SPICER, C. C. (1966). Influence of weather on respiratory disease. Bronchitis, weather and climate. Proceedings of the 3rd International Biometeorological Congress, Paris, France, 1963. Biometeriology, 2, 30. - - - , and Wilson, J. M. G. (1961). Influence of the weather on respiratory and heart disease. Lancet. 2, 338.

Humphrey, S. J. E., and WolfF, H. S. (1968). A temperature SAMI. J. Physiol. (Lond.), 194, 5P.

Lancet (1970). Hypothermia in Birmingham. Leading article, 1, 791.

MINISTRY OF HousING AND LOCAL GoVERnMENT: Report of the Parker Morris Committee (1961). Homes for Today and Tomorrow. H.M.S.O., London.

REPORT BY THE HYPOTHERMIA SUB-COMMTTEE OF THE Welfare Group of THE Society OF Medical OfFicers OF Health (1968). A pilot survey into the occurrence of hypothermia in elderly people living at home. J. Publ. Hlth, 82, 223.

Royal College of Physicians of London (1966). Report of the Committee on Accidental Hypothermia.

Williams, B. T. (1968). Oral temperatures of elderly applicants for welfare services. Geront. clin. (Basel) $10,281$. 